\title{
Abundance, infestation and disease transmission by thrips on groundnut as influenced by climatic variability at Kadiri, Andhra Pradesh
}

\author{
S. VENNILA ${ }^{1}$, RANJIT KUMAR PAUL ${ }^{2}$, M.N. BHAT ${ }^{1}$, S.K. YADAV ${ }^{1}$, K. VEMANA ${ }^{3}$, E. \\ CHANDRAYUDU ${ }^{4}$, S. NISAR ${ }^{1}$, MURARI KUMAR ${ }^{1}$, ANKUR TOMAR ${ }^{1}$, M.SRINIVASA RAO ${ }^{4}$ and M. $^{\text {.SO }}$ \\ PRABHAKAR ${ }^{4}$
}

\author{
${ }^{1} I C A R$ - National Research Centre for Integrated Pest Management, (ICAR-NCIPM), New Delhi \\ ${ }^{2} I C A R$-Indian Agricultural Statistics Research Institute (ICAR-IASRI), New Delhi \\ ${ }^{3}$ Agricultural Research Station, Kadiri, Anantapur, Andhra Pradesh \\ ${ }^{4}$ ICAR-Central Research Institute for Dryland Agriculture (ICAR-CRIDA), Hyderabad
}

E-mail: svennila96@gmail.com

\begin{abstract}
Abundance, infestation and disease transmission by thrips studied on groundnut at Kadiri of Anantapur (Andhra Pradesh) over six kharif seasons of 2011-16 indicated significantly higher abundance of thrips in 2016 over 2011 to 2015 with infestations on par among 2013, 2014 and 2016 and higher over other seasons. Peanut bud necrosis disease (PBND) transmission by thrips was significantly lower in 2015 and 2016 and higher in 2014. Associations of abundance of thrips with infestation and PBND were significant. Significant influence of PBND by the thrips infestation of only the current week implied significance of concurrent population in disease transmission.Significant positive effect of minimum temperature on incidence of PBND and negative effect of rainfall on thrips infestation were noted.Predictions of thrips abundance, infestation and PBND through multiple linear regression (MLR) models revealed positive influence of minimum temperature lagged by a week. Distribution of rainfall over its amount associated with thrips infestation besides negative role of wind with PBND was noted. Prediction models of PBND incidence combining weather and thrips abundance $\left(R^{2}: 0.39\right)$ and weather and infestation $\left(R^{2}: 0.53\right)$ showed that the PBND incidence was dependent on relative humidity and prevalent wind over previous two weeks in addition to thrips abundance or infestation.
\end{abstract}

Keywords: Groundnut, thrips, abundance, peanut bud necrosis disease, model, Kadiri

Groundnut (Arachis hypogaea L.) is an important oilseed crop grown in tropical, sub-tropical and warm temperate regions of the world. China, India, Nigeria, United States of America, Myanmar, and Indonesia grow groundnut over 23.48 million hectares (Mha) with a production of 38.32 million tonnes (Mt) (Rai et al., 2016).In India, groundnut is grown over 4.56 Mha with production and productivity of $6.77 \mathrm{Mt}$ and $1486 \mathrm{kgha}^{-1}$, respectively, with Andhra Pradesh accounting for 17.0 per cent of area and 11.8 per cent of production (Anon, 2017). Anantapur district of Andhra Pradesh is the largest producer in the State (0.11Mt) from an area of 0.89Mha (CMIE, 2010).

Groundnut crop suffers from a variety of insect pests, pathogens and weeds that cause heavy yield and monetary losses. Sap feeders (thrips and jassids) as regular insects and defoliators (tobacco and red hairy caterpillars) as sporadic/ occasional insects cause economic damage under favourable weather conditions and cultural practices, respectively.
Thrips normally found in between folded leaflets and flowers of groundnut. No single species of thrips can be studied in isolation under field conditions for their abundance and plant infestations. Occurrence of $S$. dorsalis dominantly on foliage, T. palmi on foliage and flowers, and F. schultzei on flowers has been reported (Lakshmi et al., 1995). Thrips go through six (an egg, two larval, pre-pupal, pupal stage and adult) stages in their life cycle. Hot and dry weather can lead to an increase in its population. Food consumption rate of insect increases with temperature (Dalal and Arora, 2016). Feeding by thrips results in white patches on lower surface of leaves and higher densities lead to distortion of young leaflets. Extensive feeding also predisposes plants to various fungal and bacterial pathogens that further decrease yield. Very severe infestations cause stunted plant growth.

Thrips are also economically important as virus vectors causing peanut bud necrosis disease (PBND).PBND is considered as a major disease of kharif groundnut in 
India.Basu (1995) reported 30 to 90 per cent yield losses depending upon the time of infection on plant growth. Increasing complexity of thrips in terms of species diversity and abundance, besides their role in transmission of virus diseases necessitates evolving long-term strategies to cope with future challenges posed by climate change (Prasada Rao et al. 2010). Nandgopal et al. (2008) developed weather based model to predict thrips on groundnut in Saurashtra, while Kumar et al. (2018) predicted pests of cotton in Maharashtra.Present study investigated dynamics of thrips abundance, severity of plant infestations and incidence of PBND at Kadri in Anantapur district of Andhra Pradesh (AP) in relation to climatic factors towards evolving suitable forecast models for thrips and PBND.

\section{MATERIALS AND METHODS}

\section{Study location and sampling of thrips and PBND}

Study was a part of information and communication technology (ICT) based pest surveillance implemented to study pest dynamics in relation to climate change on groundnut during kharif 2011-16 under National Innovations in Climate Resilient Agriculture (NICRA). Field observations were carried out from two fields in each of 10 villages located within $30 \mathrm{~km}$ radius of meteorological observatory of Agricultural Research Station, Kadiri of Anantapur district in Andhra Pradesh (AP). Kadiri 6 was the cultivar widely grown following standard package of practices by farmers during all seasons with dates of sowing groundnut spread between June to July second fortnights. Sampling area was approximately one-acre field, and five spots/field were randomly selected with observations made on ten plants selected per spot right from vegetative stage till crop harvest. Weekly counts of number of nymphs and adults present in top three opened leaves of a single plant (thrips abundance), number of plants showing symptoms ofthrips damage out of 10 plants (thrips infestation) and number of PBND infected plants out of 10 plants per spot were recorded. Mean thrips population (nos/three leaves/ plant), its infestation (\%) and PBND incidence (\%) were worked out for each period of observation for individual fields.

\section{Meteorological observations}

Data on weather variables viz., maximum and minimum temperature $\left(\mathrm{T}_{\max } \& \mathrm{~T}_{\min },{ }^{\circ} \mathrm{C}\right)$, morning and evening humidity (RHM \& RHE, \%), sunshine hour (SS, h/day), wind speed $\left(\mathrm{km} \mathrm{h}^{-1}\right)$, total rainfall (Rain $\left.\mathrm{mm}\right)$, and rainy days $(\mathrm{RD})$ recorded at meteorological observatory of ARS, Kadiri were gathered for study period (2011-2016). Data sets based on standard meteorological weeks (SMW) were used to assess the influence of weather parameters on thrips, their infestation and PBND.

\section{Statistical analyses}

Differences across seasons for mean thrips abundance (nos/three leaves/plant), infestation (\%) and PBND (\%) were analysed through one-way analysis of variance (ANOVA) using SAS $9.4^{\circledR}$ with their pairwise means compared by Duncan's Multiple Range Test (DMRT) following suitable data transformations. Relations of thrips infestation and thrips abundance, PBND and thrips infestation besides PBND and thrips abundance were worked out using concurrent, one and two lagged response variables as the case may be using simple linear regressions. Fluctuations in respect of $\mathrm{T}_{\max }, \mathrm{T}_{\min }$ and rainfall at Kadiri (AP) were worked out as deviations of actual weather values from long term (40 years) normals for respective SMWs of six seasons (201116) accounting periods of pest observations (31-46 SMW). Kendall's correlation coefficients between deviations of weather parameters and thrips abundance, infestation and PBND were worked out.Multiple linear regression (MLR) models for thrips abundance with weather variables lagged by one week and of infestation and PBND with weather variables lagged by both one and two weeks were developed using data of five seasons (2011-2015). Predictions of mean incidence of PBND using weather variables lagged by one and two weeks together with (1) thrips abundance and (2) thrips infestation were also made through two MLR models. The dataset for 2016 was used for validation of all the developed models along with calculation of root mean square errors (RMSE).Stepwise regression procedure for selecting the significant variables (at $5 \%$ level of significance) in MLR was adopted.

\section{RESULTS AND DISCUSSION}

One of the long-term strategy of surveillance of insect pests and diseases is to evolve their changing dynamics in a given location and help in better understanding of their changing profiles in relation to weather and to aid in development of forecast models. In this context,Kadri in Anantapur district of Andhra Pradesh, one of the hotspots for thrips and PBND was identified for multi season surveillance for six kharif seasons of 2011-2016.

\section{Seasonal dynamics of thrips, infestation and PBND}

Data sets on seasonal dynamics of thrips abundance, 


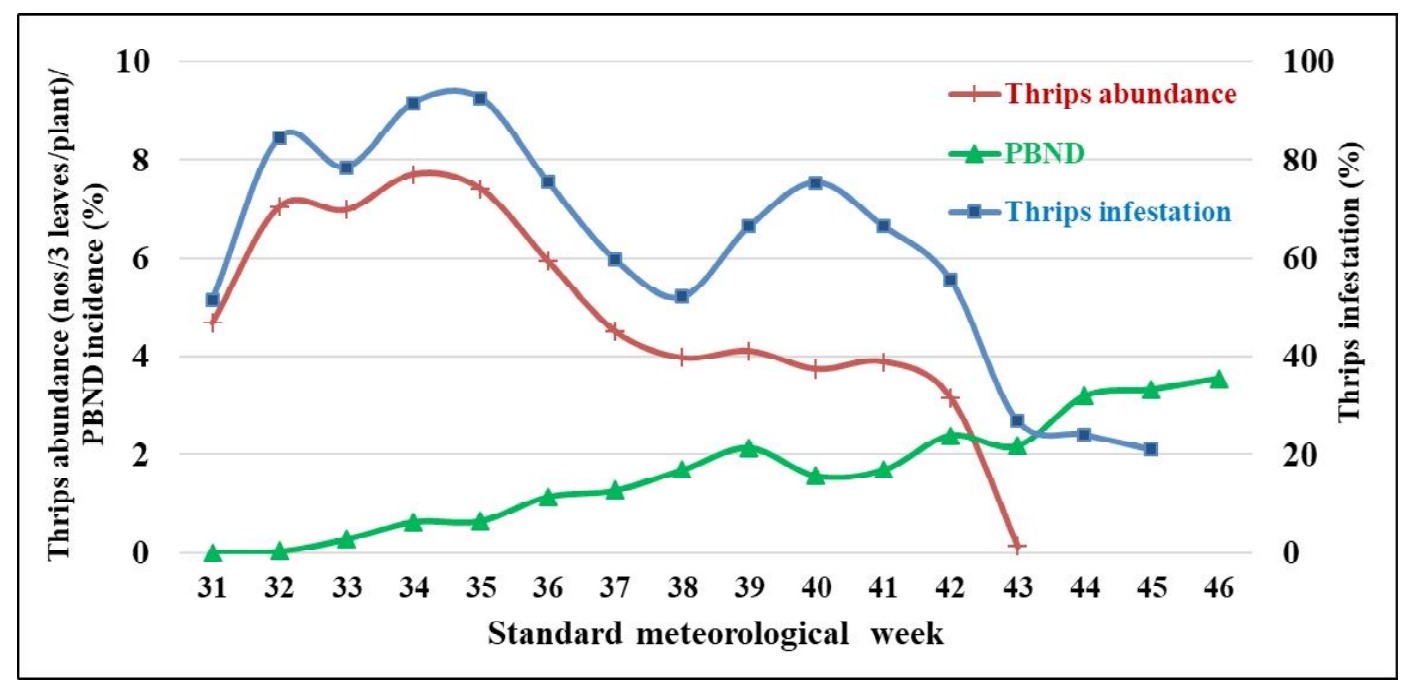

Fig.1: Seasonal dynamics of thrips abundance, infestation and PBND pooled over (2011-2016)

infestation and PBND at Kadiri, Anantapur (AP) indicated differential levels at a given time across seasons and at different periods of each season with differing periods of their peaks. While peak of thrips population (nos/3 leaves/ plant) was 4.7 during 2016, maximum infestation (\%) and PBND (\%) was 65.5 and 9.1, respectively, in 2014. Range of mean thrips population, infestation and PBND across seasons was 0.01-4.4 (nos/3 leaves/plant), 6.8-65.5 per cent and 0-9.2 per cent, respectively. Maximum of thrips population (nos/3 leaves/plant), infestation (\%) and PBND (\%) combined over all seasons ranged 0.2-8.0, 14-78 and 022, respectively.Tabassum (2014) reported maximum PBND incidence of 8.5 per cent in Anantapur district.Seasonal dynamics pooled over the study seasons (2011-2016)(Fig1) indicated similar trends of fluctuations of thrips population (nos/3 leaves/plant) and infestation (\%) with their peaks during second fortnight of August (34 \& 35 SMWs) coinciding with peak vegetative growth phase of groundnut.High fluctuation in populations of thrips and their infestations over the PBND noted was obvious due to the greater impact of biotic and abiotic factors including weather expected on these two attributes. However, progressivelyincreasing trend of PBND (\%) incidence was noted because of the fact that once virus establishes in plants, symptoms are continuous. Nevertheless, fluctuations in PBND within a given season arise due to random spot selections for sampling during each week of observation and that PBND plants wither away making unavailable for sampling during subsequent periods. Higher levels of thrips infestations on plants over PBND revealed the significance of direct damage by thrips on groundnut through feeding over their role as vector of PBND.

\section{Abundance of thrips, infestation and PBND}

Status of thrips for their abundance, infestation and PBND transmission analysed through one way ANOVA indicated significantly higher mean abundance (3.4 nos/ three leaves/plant) in 2016 over previous five seasons that were on par (1.1 to 1.7 nos/three leaves/plant). Seasons 2013, 2014 and 2016 had significantly higher but on par mean plant infestations (damage bythrips). PBND incidence (\%)was significantly higher during 2011 and 2014 over 2012, 2013, 2015 and 2016. During 2015 and 2016, significantly lowest PBND incidence was observed (Table 1) possibly due to meagre availability of virus inoculum. Importance of thrips causing direct feeding damage to plants over disease transmission at Kadiri was inferred through present study.

\section{Relationship between thrips abundance, infestaion and PBND}

Simple linear relations quantifying effect of thrips abundance on infestation and of thrips abundance as well as infestation on PBND considering current, one and two lagged values of response variables in each case indicated positive and highly significant associations $(\mathrm{p}<0.001)$ of thrips population up to three weeks with infestation as well as PBND. Such temporal associations implied direct strong relations of thrips abundance with infestations and PBND, which are manifestations of direct feeding damage and virus transmission, respectively. On the other hand, significance of only the current week infestation with PBND incidence indicated development of PBND within one week of feeding damage (Table 2). Nevertheless, infestation and PBND are dependent on thrips abundance always. Sowmya Lakshmi 
Table 1: Status of thrips abundance, infestation and PBND during 2011 to 2016

\begin{tabular}{lcccccc}
\hline Particulars & 2011 & 2012 & 2013 & 2014 & 2015 & 2016 \\
\hline Thrips (nos/3 leaves/plant) & $1.30^{\mathrm{b}}$ & $1.11^{\mathrm{b}}$ & $1.15^{\mathrm{b}}$ & $1.52^{\mathrm{b}}$ & $1.67^{\mathrm{b}}$ & $3.38^{\mathrm{a}}$ \\
& $(1.32)$ & $(1.25)$ & $(1.26)$ & $(1.39)$ & $(1.39)$ & $(1.96)$ \\
Thrips infestation (\%) & $33.39^{\mathrm{b}}$ & $30.32^{\mathrm{b}}$ & $47.13^{\mathrm{a}}$ & $49.21^{\mathrm{a}}$ & $29.29^{\mathrm{b}}$ & $42.78^{\mathrm{a}}$ \\
& $(0.61)$ & $(0.57)$ & $(0.75)$ & $(0.77)$ & $(0.56)$ & $(0.71)$ \\
PBNDincidence (\%) & $3.43^{\mathrm{a}}$ & $0.53^{\mathrm{b}}$ & $0.63^{\mathrm{b}}$ & $3.47^{\mathrm{a}}$ & $0.02^{\mathrm{c}}$ & $0.03^{\mathrm{c}}$ \\
& $(0.17)$ & $(0.05)$ & $(0.06)$ & $(0.16)$ & $(0.00)$ & $(0.00)$ \\
\hline
\end{tabular}

* In a row, values followed by the same letters are not significantly different at 5\% level of significance based on DMRT ; Figures in parentheses are square root transformed values

Table 2: Inter-relationships amongst thrips abundance, infestations and PBND

\begin{tabular}{llcl}
\hline Particulars & Equation & $\mathrm{R}^{2}$ & $\operatorname{Pr}>\mathrm{F}$ \\
\hline Thrips infestation (\%) & $0.547+0.037 * * *$ Thripsabundance & 0.25 & $<.0001$ \\
PBND (\%) & $0.039+0.027 * * *$ Thrips abundance & 0.20 & 0.0008 \\
PBND $(\%)$ & $-0.020+0.003 * * *$ Thripsinfestation & 0.10 & 0.0033 \\
\hline
\end{tabular}

*** significant at $p<0.001$ and relations pertain to concurrent observations

(2015) reported that bud necrosis was significantly and positively correlated with thrips population. Present study showed lower $\mathrm{R}^{2}$ values of $0.10-0.25$ for significant relations between any two variables of thrips abundance, infestation and PBND.

\section{Relation of thrips abundance, infestation and PBND with weather}

Weather affects the population build up and expression of symptoms of direct feeding and disease transmission by thrips. Considering period of occurrence of thrips (29-47 SMW) during kharif groundnut season at Kadiri, the calculated climatic variability over 2011 to 2016 signified an increase of $0.75^{\circ} \mathrm{C}$ and $0.91^{\circ} \mathrm{C}$ in $\mathrm{T}_{\text {max }}$ and $\mathrm{T}_{\text {min }}$, respectively besides an estimated decline in mean rainfall of $1.8 \mathrm{~mm}$ per week. Relations of deviations of weather variables with thrips revealed positive effect of increasing minimum temperature on incidence of PBND and negative effect of decreasing rainfall on thrips infestation (Table 3 ). Since thrips have shorter developmental duration greater than one week and less than two weeks prediction of thrips abundance was attempted with weather variables of only one lag $(-1)$ week. Considering that weather of past weeks influence the infestation and PBND incidence, weather variables lagged by one (-1) and two (-2) weeks were used as independent variables to work out pest-weather relations. Eight variables of weather viz., maximum and minimum temperature $\left(\mathrm{T}_{\max }\right.$ and $\left.\mathrm{T}_{\min }\right)$, morning and evening humidity (RHM\&RHE), sunshine hour (SS), wind speed (Wind), total rainfall (RF) (mm) and rainy days (RD)] were considered to generate model equations through stepwise regressions approach. Resultant variables of significance in respect of thrips abundance, infestation and PBND are given in Table 4.

$\mathrm{T}_{\min }$ lagged by one week affected all attributes of thrips viz., abundance, infestation and PBND positively.RHM of previous week had negative relation with thrips abundance and infestation, PBND had positive association with RHM lagged by two weeks. The contrasting association may have arisen due to direct and indirect effects relating to infestation and virus transmission, respectively by thrips. The positive correlation of temperature as well as negative relation of relative humidity with groundnut thrips has also been reported by Nandgopal et al.,(2008) in Saurashtra Gujarat and by Akashe et al. (2016) in Maharashtra. Negative and positive influence in respect of rainfall amount and distribution (rainy day) with thrips infestation indicated the relative importance of rain distribution over quantity. Higher rains have a mechanical washing off effect on thrips and hence could be the reduced damage symptoms following heavy rains. Nevertheless, alternating wet and dry spells are congenial for thrips development that rainy days have a positive effect on damage by thrips. Vijayalakshmi et al., (2017) reported such positive effect of rainfall on thrips numbers at Coimbatore on groundnut.

Accounting the significant associations of thrips abundance, infestation and weather variables with PBND, 
Table 3: Effect of climatic variability on thrips abundance, infestation and PBND

\begin{tabular}{lccccc}
\hline Climatic variables & $\begin{array}{c}\text { Actual means } \\
\text { of weather } \\
(2011-16)\end{array}$ & $\begin{array}{c}\text { Quantified } \\
\text { climatic } \\
\text { variability }\end{array}$ & $\begin{array}{c}\text { Thrips abundance } \\
\text { (Nos./3leaves/plant) }\end{array}$ & $\begin{array}{c}\text { Thrips } \\
\text { infestation(\%) }\end{array}$ & $\begin{array}{c}\text { PBND } \\
(\%)\end{array}$ \\
\hline $\mathrm{T}_{\max }\left({ }^{\circ} \mathrm{C}\right)$ & 31.2 & $0.80^{* * *}$ & 0.001 & 0.04 & 0.04 \\
$\mathrm{~T}_{\min }\left({ }^{\circ} \mathrm{C}\right)$ & 22.1 & $0.92^{* * *}$ & -0.12 & 0.06 & $0.21^{* *}$ \\
Rainfall $(\mathrm{mm} /$ week) & 16.5 & $-1.9 * * *$ & -0.02 & $-0.24 * *$ & -0.01 \\
\hline
\end{tabular}

$* * *$ significant at $p<0.001$ based on ' $t$ ' test; ** significance of ' $r$ ' values at $p<0.01$

Table 4: Weather based prediction models for thrips abundance, infestation and PBND

\begin{tabular}{llll}
\hline Forecast variable & Model equation & $\mathrm{R}^{2}$ & $\operatorname{Pr}>\mathrm{F}$ \\
\hline Thrips abundance & $=0.332+0.096 \mathrm{~T}_{\text {min-1 }}-0.015 \mathrm{MRH}_{-1}+0.025 \mathrm{Wind}_{-1}$ & 0.35 & $<.0001$ \\
(Nos./3leaves/plant) & $=0.758-0.241 \mathrm{~T}_{\text {max-1 }}+0.438 \mathrm{~T}_{\text {min-1 }}-0.004 \mathrm{MRH}_{-2}$ & 0.28 & $<.0009$ \\
Thrips infestation (\%) & $-0.024 \mathrm{RF}_{-2}+0.364 \mathrm{RD}_{-2}$ & & $<.0001$ \\
& $=-0.437+0.013 \mathrm{~T}_{\text {min-1 }}+0.005 \mathrm{MRH}_{-2}-0.016 \mathrm{Wind}_{-2}$ & 0.36 & \\
PBND (\%) &
\end{tabular}

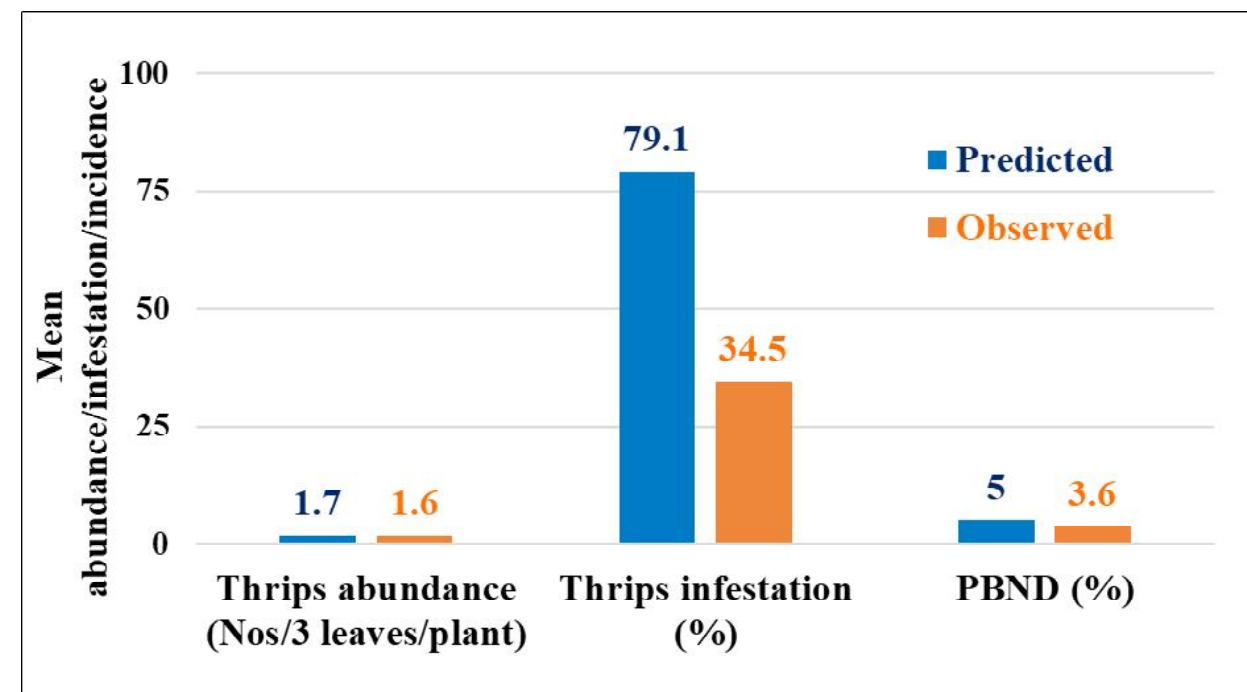

Fig.2: Validation of weather based predictions (2016)

models were generated to forecast PBND using (1) thrips abundance and (2) infestaion lagged by one week combined with weather variables lagged by one as well as two weeks.

PBND $(\%)=-0.0385+0.034$ thrips abundance ${ }_{-1}+0.003$ RHM $_{-2}-0.014$ Wind $_{-2} ; \quad \mathrm{R}^{2}: 0.39 * *$ (1) PBND $(\%)=-0.14+0.004$ thrips infestation ${ }_{-1}+0.003$ RHM $_{-2}-0.014$ Wind $_{-2}$; $\mathrm{R}^{2}: 0.53 * *(2)$

Prediction of PBND (\%) combining abundance or infestation with weather variables had higher coefficient of determination $\left(\mathrm{R}^{2}\right)$ over use of weather variables alone. In these equations, positive impact of morning relative humidity and wind of previous two weeks remained the same indicating possible forecasts of PBND incidence two weeks in advance besides leading to recommendation of thrips management within the following week to limit disease transmission. It is proposed that higher prediction possibility of PBND with thrips infestation on plants over thrips abundance has possibly arisen due to the inclusive nature of PBND for infestation due to thrips while sampling.

\section{Validation of PBND prediction}

Validation of weather based prediction models for thrips population (nos/3 leaves/plant), infestation (\%) and PBND (\%) incidence based on seasonal means considering observed dynamics of 2016 indicated 90.3, 43.6 and 70.4 per cent agreement, respectively (Fig 2). RMSEs in respect of thrips abundance, infestation and PBND were 2.11, 6.37 and 0.64 , respectively indicating order of model performance 
to be $\mathrm{PBND}>$ thrips abundance $>$ thrips infestation. Combined model equation(1) considering thrips abundance and weather had a mean PBND (\% incidence) prediction accuracy of 46.9 per cent lesser by 43.4 per cent of only weather based prediction. Weather based predictions of thrips population (nos/3 leaves/plant), infestation (\%) and PBND(\%) incidence proved to be better despite significant inter-relations of all three variables worked out through the present study (Table 1). On the other hand, the model equation (2) incorporating thrips infestation and weather led to over prediction by 71 per cent indicating the relative insignificance of thrips infestation with PBND incidence. Over prediction of PBND with thrips infestation in equation(2) also confirms the inclusiveness of the disease always with thrips infestation as proposed earlier. The model adequacy was examined in terms of residuals diagnostics. It was found that the residuals obtained from fitted models were uncorrelated (tested using run test) and they followed asymptotically normal distribution (tested using Kolmogorv Smirnov test). Validations in toto suggested possibility of weather based prediction of individual attributes of thrips perse and better prediction of PBND using thrips abundance over infestations along with weather.

\section{CONCLUSION}

Studies on thrips population dynamics, thrips infestation and PBND incidence and role of climatic factors to evolve forecasts based on datasets of six successive kharif seasons (2011-2016) at Anantapur (Telengana State) indicated prevalence of thrips and their damage throughout kharif season with peak activity during vegetative and flowering stage of groundnut at Kadiri (AP). Increasing trend of thrips abundance and infestation and declining PBND over periods between 2011 and 2016 was observed at Kadiri (AP). Greater damage in term of plant infestation to groundnut crop is due to direct feeding over PBND transmitted virus by thrips. While plant infestations by thrips and PBND incidence are directly and significantly proportional to thrips abundance, virus transmission by thrips is only dependent on concurrent population of thrips indicating the inclusivity of infestations with PBND and vice versa. While source of inoculum in the ecosystem is the primary factor, thrips abundance and prevalent weather play significant role in PBND incidence. Significantly increasing minimum temperature and decreasing rainfall over six kharif seasons had positive and negative impacton PBND and thrips infestation, respectively. Effect of climate factors on thrips abundance, infestation and PBND incidence is multi dimensional and complex in nature although minimum temperature lagged by one week affected all attributes of thrips viz., abundance, infestation and PBND positively. Weather based predictions of thrips in respect of population abundance and of PBND are advocated in addition to use of combined model of PBND forecast using thrips abundance and weather over infestation for better results and in turn for better management damage and disease transmitted by thrips,

\section{ACKNOWLEDGEMENT}

Authors gratefully acknowledge the funding by ICAR through 'National Innovations in Climate Resilient Agriculture (NICRA)', and different persons involved in data collection, entry and uploads from real time pest surveillance centre of Kadiri, Anantapur, Andhra Pradesh.

\section{REFERENCES}

Akashe, V.B., Jadhav, J.D., Bavadekar, V.R., Pawar, P.B. and Amrutsagar, V. M. (2016). Forewarning models for sunflower thrips (Thrips Palmi Karny) in western Maharashtra scarcityzone. J. Agrometeorol., 18(1):6870 .

Anon.(2017).Agricultural Statistics ata Glance2016. Directorate of economics and statistics, Department of Agriculture and Cooperation and Farmer's Welfare, Government of India.

Basu, M.S. (1995). Peanut Bud Necrotic Disease: Activities in the Indian national program. In: A.A.M. Buiel,J.E. Parleviliet,and J.M.Lenne (eds.) Recent studies on peanut bud necrotic disease. Proceedings of a meeting 20 March 1995, International Crop Research Institute for Semi-Arid Tropics-Asia Center, Patancheru, Telangana, India.

CMIE, (2010). Executive Summary-GDP Growth. Centre for monitoring Indian Economy Pvt. Ltd. Apple Heritage, Mumbai.April 2010.

Dalal, P.K. and Arora, R. (2016). Impact of temperature on food consumption and nutritional indices of tomato fruit borer. J. Agrometeorol., 18(1):62-67.

Kumar, Amrender, Nemade, P.W., Sharma, R., Tanwar, R.K., Chattopadhyay, C., Wanjari, S.S. and Rathod, T.H. (2018). Statistical forewarning models for sucking pests of cotton in Maharashtra. J. Agrometeorol., 20(1):6265. 
Lakshmi, K. V., Wightman, J. A., Reddy, D. V. R.., Rao, G. V. R., Buiel,A. A. M., Reddy, D. D. R., Parker, B. L., Skinner, M andLewis, T.(1995). Transmission of peanutbud necrosis virus by Thrips palmi in India. Plenum Publishing Co. Ltd, London, USA, Thrips biology and management: Proceedings of the 1993 International Conference on Thysanoptera, pp. 179-184.

Nandgopal, V., Prasad, T.V., Gedia, M.V. and Makwana, A.D. (2008). Influence of weather parameters on the population dynamics of sesbania thrips (Caliothrips indicus Bagnall) in groundnut in Saurashtra region. $J$. Agrometeorol., 10(2):175-177.

Prasada Rao,G.S.L.H.V., Rao, V.U.M., and Rao, G.G.S.N. (2010). Climate change and agriculture over India. PHI Learning Pvt. Ltd., India.
Rai, S.K., Deeksha, Charak and Rajeev Bharat. (2016). Scenario of oilseed crops across the globe. Plant Archives 16: 125-132.

Sowmya Laksmi, G. (2015). Epidemiology and management of bud necrosis and stem necrosis diseases affecting groundnut (Arachis hypogaea L.). M.Sc Thesis, Acharya N.G. RangaAgricultural University, Guntur, India.

Tabassum, A. (2014). Identification of resistant sources to groundnut bud necrosis disease (GBND) in groundnut (Arachis hypogaea) Thesis submitted to the Acharya N G RangaAgricultural Universityp. 155.

Vijayalakshmi, G., Ganapathy, N. and Kennedy, J.S. (2017). Influence of weather parameters on seasonal incidence of thrips and groundnut bud necrosis virus in groundnut (Arachis hypogea L.). J. Entomol. Zool. Studies, 5: 107110. 